\title{
OPEM
}

www.opem.org

Oriental Pharmacy and Experimental Medicine 2008 8(4), 349-353

DOI 10.3742/OPEM.2008.8.4.349

\section{Anti-diabetic activity of Thespesia lampas Dalz \& Gibs on alloxan induced rats}

\author{
Jayakar B and Sangameswaran B* \\ Vinayaka Mission's of pharmacy, Vinayaka Missions University, Kondappanaickan patty, Salem-636 008, Tamil \\ Nadu, India
}

Received for publication August 07, 2007; accepted June 24, 2008

\begin{abstract}
SUMMARY
Anti-diabetic effect was observed with Thespesia lampas Dalz \& Gibs (Family: Malvaceae) when given as a root extract in normal as well as alloxan induced diabetic rats. The effects, however, were more pronounced in diabetic animals in which administration of plant extract for 15 days after alloxan induced diabetes, significantly reduced blood glucose levels. After alloxan induced diabetes it was observed that both standard drug (glibenclamide) and aqueous extract of Thespesia lampas were significantly superior to control in reducing blood sugar on long term treatment (15 days). The aqueous extract of T. lampas ( 300 and $600 \mathrm{mg} / \mathrm{kg}$ ) reduced the blood glucose levels from $349.2 \pm 7.2$ to $120.7 \pm 4.6$ and $346.3 \pm 3.4$ to $101.8 \pm 6.3$, respectively. The data suggested that T. lampas could be of beneficial in diabetes mellitus in controlling blood sugar. The present investigation established pharmacological evidence to support the folklore claim as an anti-diabetic.
\end{abstract}

Key words: Anti-hyperglycemic, Alloxan, Thespesia lampas Dalz \& Gibs

\section{INTRODUCTION}

Diabetes mellitus is a common metabolic and endocrine disorder, characterized by chronic hyperglycaemia and disturbance of carbohydrate, fat and protein metabolism associated with absolute or relative deficiency of insulin secretion and/or insulin action (Bennet, 1998). The dramatic increase in the prevalence of diabetes can be attributed to several factors. Globally, diabetes has showed the spread of 'modern life style' and can be linked to an increasingly overweight and sedentary population (Moller, 2001). Although, there are numerous traditional medicinal plants

*Correspondence: Sangameswaran B, Vinayaka Mission's of pharmacy, Vinayaka Missions University, Kondappanaickan patty, Salem-636 008, Tamil Nadu, India. Tel: +914272400174; Fax: +91427 2400174; E-mail: sangar1970@yahoo.co.in reported to have hypoglycaemic properties (Aiman, 1970) many of them proved to be not very effective in lowering glucose levels in severe diabetes (Nagarajan et al., 1987). Further, most of the hypoglycaemic agents used in allopathic medicine are reported to have side effects in the long run (Khan and Shechter, 1991). In folk/tribal medical practice many plants are used to treat diabetes mellitus in South India. Most of these medicinal plants are not scientifically validated for their therapeutic efficacy and safety. Scientific studies on these plants are likely to provide invaluable anti-diabetic drug.

\section{MATERIALS AND METHODS}

\section{Plant material}

The plant parts were collected from the foot hills of Yercaud, Salem, in the month of September 2005. 
The plant was identified and authenticated by the experts in the department of Botany, Government Arts College, Salem, Tamil Nadu India. A voucher specimen (TL-12) has been kept in our museum for future reference. The plant material was collected and shade dried at room temperature for 10 days and coarsely powdered and the powder was passed through sieve No.60

\section{Preparation of the Extract}

The powdered material of root of T. lampas was extracted separately by cold maceration with distilled water. After extraction, the extract was concentrated under reduced pressure. The dried extract was subjected to various chemical tests to detect the presence of different phytoconstituents and was found the alkaloids, tannins, glycosides traces of flavonoids etc.

\section{Animals}

Male albino rats, 8 - 12 weeks old with average weight of $100-125 \mathrm{~g}$ were purchased from M/S Venkateshwara enterprises (P) Ltd, Bangalore and used for the study. They were housed in polypropylene cages and fed with standard chow diet and water ad libitum. The animals were exposed to alternate cycle of $12 \mathrm{~h}$ of darkness and light each. Before each test, the animals were fasted for at least $12 \mathrm{~h}$. The experimental protocols were approved by the Institutional Animal Ethics Committee and were cleared by the same (IAEC NO: P.Cog-1/06).

\section{Toxicity evaluation in mice (Ghosh, 1994)}

To determine acute toxicity of a single oral administration of the aqueous extract of $T$. lampas different doses $(200,300,400,500,600$ and $700 \mathrm{mg} / \mathrm{kg}$ ) were administrated to different groups of mice. Mortality and general behavior of the animals were observed periodically for 48 $h$. The animals were observed continuously for the initial $4 \mathrm{~h}$ and intermittently for the next six $\mathrm{h}$ and then again at $24 \mathrm{~h}$ and $48 \mathrm{~h}$ following drug administration.

\section{Alloxan-induced diabetic rats}

The rats were administered alloxan monohydrate (S.D Fine chemicals Ltd., Boisar) dissolved in sterile normal saline at the dose of $150 \mathrm{mg} / \mathrm{kg}$ body weight i.p (Interaperitoneally). Since alloxan could evoke fatal hypoglycemia as a result of massive insulin release, rats were treated with $15 \mathrm{ml} \mathrm{20 \%}$ glucose solution i.p, $6 \mathrm{~h}$ after alloxan treatment. The rats were then kept for next $24 \mathrm{~h}$ with free access to $5 \%$ glucose solution to prevent hypoglycemia. After a fortnight, alloxan monohydrate treated rats having hyperglycemia (evidenced by blood glucose range of $300-350 \mathrm{mg} / 100 \mathrm{ml}$ ) were selected for the experiment (Sheweita et al., 2002). These diabetic rats were divided into 5 groups as follows. Group I, Normal control group of rats were given food and water; Group II (un treated) diabetic rats given $0.5 \mathrm{ml}$ of $5 \%$ Tween 80; Group III, diabetic rats given $0.5 \mathrm{ml}$ of $5 \%$ Tween 80 containing glibenclamide $(500 \mu \mathrm{g} / \mathrm{kg})$; Group IV and V diabetic rats were

Table 1. Diabetic activity of aqueous extract of T. lampas on alloxan induced rats

\begin{tabular}{lrcrrr}
\hline \multirow{2}{*}{ Treatment $(\mathrm{mg} / \mathrm{kg})$} & \multicolumn{5}{c}{ Changes in blood Glucose levels $(\mathrm{mg} / \mathrm{dl})$} \\
\cline { 2 - 5 } & \multicolumn{1}{c}{$1^{\text {st }}$ day } & \multicolumn{1}{c}{$4^{\text {th }}$ day } & $7^{\text {th }}$ day & $10^{\text {th }}$ day & $15^{\text {th }}$ day \\
\hline Normal & $95.3 \pm 3.7$ & $95.8 \pm 2.6$ & $95.5 \pm 2.5$ & $95.5 \pm 2.3$ & $95.6 \pm 2.2$ \\
Alloxan 150 p.o. & $346.2 \pm 4.2$ & $365.5 \pm 4.1$ & $374.2 \pm 3.8$ & $386.8 \pm 3.5$ & $402.0 \pm 3.5$ \\
Glibenclamide 0.5 & $348.3 \pm 7.2$ & $335.8 \pm 3.9$ & $242.5 \pm 3.6$ & $202.3 \pm 2.9^{* *}$ & $114.3 \pm 2.9$ \\
Aqueous extract 300 & $349.2 \pm 7.1$ & $339.0 \pm 7.0^{* *}$ & $259.3 \pm 6.2^{* *}$ & $215.5 \pm 5.8^{* *}$ & $120.7 \pm 4.5^{* *}$ \\
Aqueous 600 & $346.3 \pm 3.4$ & $335.0 \pm 14.6^{* *}$ & $236.5 \pm 6.3^{* *}$ & $190.0 \pm 8.0^{* *}$ & $101.8 \pm 6.3$ \\
\hline
\end{tabular}

Values are mean \pm S.E.M. $\mathrm{n}=6$. When compared with diabetic control ${ }^{* *} p<0.01$ (One way ANOVA Followed by Dunnette multiple comparison test) 
given $(300$ and $600 \mathrm{mg} / \mathrm{kg}$ ) T. lampas (aqueous extract) in $0.5 \mathrm{ml} 5 \%$ Tween 80 , respectively.

The treatment continued daily for 15 days. In the untreated control (diabetic) group, 1 animal died on $5^{\text {th }}$ day and 1 on the $7^{\text {th }}$ day. Blood drop was collected from the tail, for glucose estimation just before drug administration on $1^{\text {st }}$ day and $1 \mathrm{~h}$ after drug administration on days $1,4,7,10$ and 15 (Table 1).

\section{Glucose tolerance test}

Overnight fasted rats were divided into 4 groups. Group one was kept as normal control which received 5\% Tween 80 (0.5 ml, p.o), Group II diabetic rats received standard drug $(500 \mu \mathrm{g} / \mathrm{kg})$ and groups III and IV diabetic rats received aqueous extract of T. lampas 300 and $600 \mathrm{mg} / \mathrm{kg}$ respectively. The rats of all the groups were loaded with glucose ( $3 \mathrm{~g} / \mathrm{kg}$, p.o) (Babu et al., 2003). Thirty min after the administration of the standard and sample, blood samples were collected at 30, 60 and $120 \mathrm{~min}$ after the glucose loading and blood glucose levels were determined (Table 2).

\section{Statistical evaluation (Woodson, 1987)}

All the data are presented as mean \pm S.E.M. The differences between group were evaluated by oneway analysis of variance (ANOVA) followed by the Dunnette multiple comparisons test. $P<0.01$ were considered to be significant.

\section{RESULTS}

The hyperglycaemic animals showed significant decrease in the glucose level on long term treatment for 15 days model at the doses of 300 $\mathrm{mg} / \mathrm{kg}$ and $600 \mathrm{mg} / \mathrm{kg}$ of aqueous extract of $T$. lampas (Group-IV, V). The effect of the extract of $T$. lampas on glucose levels in alloxan induced diabetic rats is shown in Table 1. The initial blood glucose levels of the diabetic rats selected for the study were in the range of above $340 \mathrm{mg} / 100 \mathrm{dl}$. In the aqueous extract (300 and $600 \mathrm{mg} / \mathrm{kg}$ ) treated rats, the blood glucose levels steadily decreased and it was 120 and $101 \mathrm{mg} / 100 \mathrm{dl}$ respectively on the $15^{\text {th }}$ day.

\section{Oral glucose tolerance test}

In single oral treatment, thirty min the blood glucose values increased above control with the extract and after thirty min values decreased steadily. The blood glucose levels were significantly higher at $30 \mathrm{~min}$ after glucose loaded in control as well as treated groups of animals. Thereafter, a decreased trend in the blood glucose values were recorded upto $120 \mathrm{~min}$. At $120 \mathrm{~min}$, the aqueous extract ( 300 and $600 \mathrm{mg} / \mathrm{kg}$ ) treated animals, blood glucose level was significantly decreased from $240.2 \pm 3.9$ to $226.3 \pm 4.3$ and $240.2 \pm 4.7$ and $218.5 \pm$ 3.8 (Table 2).

\section{Body Weight}

The body weight was slightly increased in the normal control rats compared to initial body weight whereas in the diabetic control rats there was a significantly decreased in the body weight. Glibenclamide $(500 \mu \mathrm{g} / \mathrm{kg})$ as well as aqueous extract of T. lampas (300 and $600 \mathrm{mg} / \mathrm{kg}$ ) treatment

Table 2. Effects of T. lampas on oral glucose tolerance test in alloxan induced diabetic rats

\begin{tabular}{lcccc}
\hline \multirow{2}{*}{ Treatment (mg/kg, p.o.) } & \multicolumn{4}{c}{ Changes in blood Glucose levels in (mg/dl) in mints } \\
\cline { 2 - 5 } & 0 & 30 & 60 & 120 \\
\hline Normal $10 \mathrm{ml} / \mathrm{kg}$ & $95.2 \pm 2.9$ & $169.2 \pm 3.0$ & $134.0 \pm 2.6$ & $110.5 \pm 1.9$ \\
Diabetic control $10 \mathrm{ml} / \mathrm{kg}$ & $312.3 \pm 4.8$ & $318.0 \pm 4.5$ & $320.5 \pm 4.6$ & $327.5 \pm 4.7$ \\
Aqueous extract 300 & $240.2 \pm 3.9^{* *}$ & $236.5 \pm 4.5^{* *}$ & $227.8 \pm 4.8$ & $226.3 \pm 4.3^{* * *}$ \\
Aqueous extract 600 & $240.6 \pm 4.7$ & $230.2 \pm 4.1^{* *}$ & $233.2 \pm 3.2^{* *}$ & $218.5 \pm 3.8^{* *}$ \\
\hline
\end{tabular}

Values are mean \pm S.E.M. $(\mathrm{n}=6)$ When compared with diabetic control ${ }^{* *} p<0.01$ (One way ANOVA Followed by Dunnette multiple comparison test) 
Table 3. Changes in Body weight in the treatment of aqueous extract of T. lampas on alloxan induced diabetic rats

\begin{tabular}{lccc}
\hline \multirow{2}{*}{ Group } & \multicolumn{3}{c}{ Change in body weight in gm } \\
\cline { 2 - 4 } & Initial & $7^{\text {th }}$ Day & $15^{\text {th }}$ Day \\
\hline Normal & $122 \pm 0.2$ & $143.0 \pm 1.0$ & $160.8 \pm 2.2$ \\
Diabetic control & $124 \pm 0.2$ & $101.7 \pm 1.0$ & $98.3 \pm 1.7$ \\
Glibenclamide $500 \mu \mathrm{g} / \mathrm{kg} \mathrm{p.o}$ & $124 \pm 0.4$ & $136.7 \pm 1.7^{* *}$ & $146.2 \pm 1.1^{* *}$ \\
Aqueous extract $300 \mathrm{mg} / \mathrm{kg}$ & $121 \pm 0.1$ & $148.8 \pm 1.4^{* *}$ & $152.8 \pm 1.4^{* *}$ \\
Aqueous extract $600 \mathrm{mg} / \mathrm{kg}$ & $122 \pm 0.1$ & $162.2 \pm 1.5^{* *}$ & $178.0 \pm 2.2^{* *}$ \\
\hline
\end{tabular}

Values are mean \pm S.E.M. $\mathrm{n}=6$. When compared with diabetic control ${ }^{* *} p<0.01$ (One way ANOVA Followed by Dunnette multiple comparison test)

significantly prevent this reduction in body weight. However, the incresing in body weight was significant when compared to the final weight of normal control group (Table 3).

\section{DISCUSSION}

In the present study, the methanol and aqueous extracts of roots of T. lampas at doses of 300 and 600 $\mathrm{mg} / \mathrm{kg}$ b.w. could produce a significant fall in blood glucose levels in diabetic rats, after 15 days treatment. The phytochemical screening of both the extracts of $T$. lampas revealed the presence of flavonoids, phenolic acids, triterpenoids and tannins. Flavonoids, steroids/ triterpenoids, and phenols are known to be bioactive anti-diabetic principles (Atta-Ur-Rhemann and Khurshid, 1989). Flavonoids are known to regenerate the damaged beta cells in the alloxan diabetic rats (Ivorra et al., 1989).

The anti-diabetic effect of both the extracts of $T$. lampas may be due to the presence of more than one anti-hyperglycemic principle and their synergistic properties. In this study, the anti-hyperglycemic activity caused by glibenclamide in alloxan-induced diabetic rats is an indication of the presence of some beta cells, as glibenclamide is known to stimulate insulin secretion from beta cells. The extracts of T. lampas may have stimulating effect on the remnant beta cells. However, further experiments are required to elucidate the exact mechanism of action. Further studies will be focused on determination of the mechanism of action, as well as on the isolation of bioactive principles.

\section{REFERENCE}

Aiman R. (1970) Recent research in indigenous antidiabetic medicinal plants, An Overall Assessment. Indian J. physiol. Pharmacol. 14, 65-75.

Atta-Ur-Rhemann, Khurshid Zaman. (1989) Medicinal plants with hypoglycemic activity. J. Ethnopharmacol. 26, 1-55.

Babu V, Gangagadevi T, Subramaniam A. (2003) Anti diabetic activity of ethanolic extract of Cassia kleinii leaf in streptozotocin-induced Diabetic rats and isolation of an active fraction and toxicity evaluation of the extract. Indian J. Pharmacol. 35, 290-296.

Bennet PH. (1998) Joslin's. Diabetes Mellitus, Kahan RC, Weir GC, eds Baltimore, international publication Waverley p 193-200.

Ghosh M. (1994) Fundamentals of Experimental pharmacology 2nd edition p 158-159, Scientific book agency, Kolkatta.

Ivorra MD, Paya M, Villar A. (1989) A review of Natural Products and Plants as Potent antidiabetic drugs. J. Ethnopharmacol. 27, 243-275.

Khan CR, Shechter Y. (1991) Insulin oral hypoglycaemic agents, and the pharmacology of endocrine pancreas. In: Goodman \& Gilman's. The Pharmacological Basis of Therapeutics 8th edition p 1463-1495, Pergamon Press, New York.

Moller DE. (2001) New drug targets for type 2 diabetes and metabolic syndrome. Nature 414, 821827.

Nagarajan S, Jain HC, Aulakh GS. (1987) Indigenous plants used in the control of Diabetes. (Publication and Information directorate), C.S.I.R, New Delhi, 588-589.

Pullock K, Mukarjee. (2002) Pharmacological Evaluation of Herbal Drugs, Quality control herbal drugs 1 st 
edition, p 527, Business horizons New Delhi.

Sheweita SA, Newair AA, Mansour HA, Yousef M.

(2002) Effect of some hypoglycemic herbs on the activity of phase I and phase II drug-metabolizing enzymes in alloxan-induced diabetic rats, Toxicity
174, 131-139.

Woodson RF. (1987) Statistical Methods for the Analysis of Biomedical Data-Probability and Mathaematical Statistical. Wiley, Chichester 315-316. 